\title{
Status of Nomenclatural Types in the Approved Lists of Bacterial Names
}

\author{
Request for an Opinion
}

\author{
P. H. A. SNEATH \\ Department of Microbiology, Leicester University, Leicester, England LE1 7RH
}

\begin{abstract}
The Approved Lists of Bacterial Names form the new starting document for bacterial nomenclature, and therefore it is implied that the nomenclatural types given there should be accepted as correct. The Judicial Commission is requested to issue an Opinion confirming this. A list is given of genera whose type species differ from those previously accepted. Two of these, Nocardia and Pasteurella, have in the Approved Lists type species contrary to those in an earlier Opinion, and the Commission is also requested to confirm these changes.
\end{abstract}

The Approved Lists of Bacterial Names (15) was prepared by an Ad Hoc Committee of the Judicial Commission in accordance with Commission Minutes 22 (14) and 33 (9) and along lines described in the first draft of the Lists (1). The Approved Lists form the new starting document for names of bacterial taxa under the Revised Code (13).

The Ad Hoc Committee was required to consult with Subcommittees of the ICSB and with other experts on names to be placed on the Lists and on the type strains for species and subspecies. In view of the innovative nature of the enterprise and the limited time before publication, the Ad Hoc Committee had to make a number of decisions on matters of nomenclature that might otherwise have taken many years to determine through the normal channels of $\mathrm{Re}$ quests for Opinions. It therefore in general accepted the advice given to it on nomenclatural types.

It was implied in the concept of the Approved Lists (as the new starting document) that the types listed therein should thenceforward be the correct nomenclatural types. This was not explicitly stated in the Revised Code.

The present Request, therefore, is to ask for an Opinion confirming that the types in the Approved Lists are the correct ones, but without prejudice to the power of the Commission to review individual cases. It is also to ask that the Opinion confirm the types in the Approved Lists in those few cases where they are in conflict with an earlier Opinion.

No attempt has been made to list changes in type strains. Such an endeavour would be impracticable, and most cases would have to be reevaluated by the experts who first considered them. Any pressing cases can be drawn to the attention of the Commission under Rule 18i of the Revised Code (13), but it is to be hoped that very few will need examining. However, Table 1 shows the small number of genera where the type species in the Approved Lists are different from those generally accepted in the past. Cases under consideration by the Commission-the family name Enterobacteriaceae $(6,7,12)$ and the type species of the genera Eubacterium (4), Flavobacterium (8), and Spirochaeta (3)-are not reviewed here.

Two genera have, in the Approved Lists, type species that are in conflict with those given in an earlier Opinion of the Judicial Commission. By Opinion 13 (11), the type species of the genus Nocardia is Nocardia farcinica. The genus was omitted in error in the published Opinion (11), but authority was given elsewhere $(5,10)$; also, see the Revised Code (13). The type species of the genus Pasteurella is Pasteurella choleraegallinarum (11). In the Approved Lists the type species are, respectively, Nocardia asteroides and Pasteurella multocida. The second case also requires the rejection of the species name Pasteurella gallicida. This species has the same type strain (NCTC 10322) in the Approved Lists as $P$. multocida and is therefore an objective synonym. The citations of these names are given (2, 15), respectively, as $P$. gallicida (Burrill 1883) Buchanan 1925 and $P$. multocida (Lehmann and Neumann 1899) Rosenbusch and Merchant 1939. Therefore, unless $P$. gallicida is suppressed, it would have to replace $P$. multocida under Rule 24b of the Revised Code (13) because of its earlier date of publication.

The Commission is therefore asked to clarify the situation by issuing an Opinion to the following effect. First, the types in the Approved Lists are confirmed as the nomenclatural types but without prejudice to the powers of the Commission to amend them and without reference to the 
TABLE 1. Genera whose type species in the Approved Lists are different from those accepted earlier

\begin{tabular}{|c|c|c|}
\hline Genus $^{a}$ & $\begin{array}{l}\text { Type species in } \\
\text { the Lists }\end{array}$ & Previous type species ${ }^{b}$ \\
\hline Acinetobacter & A. calcoaceticus & A. anitratus $s^{c}$ or A. stenohalis ${ }^{c}$ \\
\hline Beneckea & B. campbellii & B. labra \\
\hline Borrelia & B. anserinum & B. gallinarum ${ }^{e}$ \\
\hline Cellulomonas & C. flavigena & C. biazotea \\
\hline Cristispira & C. pectinis & C. balbianii ${ }^{c}$ \\
\hline Frankia & F. alni & F. subtilis ${ }^{e}$ \\
\hline Halobacterium & H. salinarium & H. marismortuis ${ }^{e}$ \\
\hline Halococcus & H. morrhuae & H. littoralis ${ }^{e}$ \\
\hline Leptospira & L. interrogans & L. icterohaemorrhagiae ${ }^{e}$ \\
\hline Methanobacterium & $M$. formicicum & $M$. soehngenii ${ }^{c}$ \\
\hline Nocardia & N. asteroides & N. farcinica f $^{c, f}$ \\
\hline Pasteurella & P. multocida & $\begin{array}{l}P \text {. choleraegallinarum }{ }^{c, f} \text { (with suppression of } P \text {. gallicida as an } \\
\text { objective synonym of } P \text {. multocida despite Rule } 24 \mathrm{~b} \text { ) }\end{array}$ \\
\hline Spirillum & S. volutans & S. undula ${ }^{c}$ \\
\hline Thiospirillum & T. jenense & T. sanguineum ${ }^{c}$ \\
\hline Toxothrix & T. trichogenes & T. ferrugineum ${ }^{e}$ \\
\hline
\end{tabular}

${ }^{a}$ The cases Eubacterium, Flavobacterium, and Spirochaeta are not considered (see text).

${ }^{b}$ Authority for the type status is Index Bergeyana (2) unless otherwise noted.

${ }^{c}$ By subsequent designation.

${ }^{d}$ By original designation.

e By monotypy.

$f$ Opinion 13 (11).

genera Eubacterium, Flavobacterium, and Spirochaeta, which are at present under consideration by the Commission. Second, the type species of the genus Nocardia nom. approb. is Nocardia asteroides nom. approb. (thus reversing the decision in Opinion 13). Third, the type species of the genus Pasteurella nom. approb. is Pasteurella multocida nom. approb. (likewise reversing the decision in Opinion 13), and the objective synonym Pasteurella gallicida nom. approb. is placed on the list of nomina rejicienda.

\section{REPRINT REQUESTS}

Address reprint requests to: P. H. A. Sneath, Department of Microbiology, Leicester University, Leicester, England LE1 7RH.

\section{LITERATURE CITED}

1. Ad Hoc Committee of the Judicial Commission of the ICSB. 1976. First draft, approved lists of bacterial names. Int. J. Syst. Bacteriol. 26:563-599.

2. Buchanan, R. E., J. G. Holt, and E. F. Lessel, Jr. (ed.). 1966. Index Bergeyana. The Williams \& Wilkins Co., Baltimore.

3. Canale-Parola, E. 1981. Proposal that Spirochaeta stenostrepta Zuelzer replace Spirochaeta plicatalis Ehrenberg as the type species of the genus Spirochaeta Ehrenberg. Request for an Opinion. Int. J. Syst. Bacteriol. 31:105106.

4. Cato, E. P., L. V. Holdeman, and W. E. C. Moore. 1981. Designation of Eubacterium limosum (Eggerth) Prévot as the type species of Eubacterium. Request for an Opinion. Int. J. Syst. Bacteriol. 31:209-210.

5. Editorial Board. 1953. Status of generic names of bacteria proposed by Trevisan. Int. Bull. Bacteriol. Nomencl. Taxon. 3:87-108.

6. Ewing, W. H., J. J. Farmer III, and D. J. Brenner. 1980.
Proposal of Enterobacteriaceae fam. nov., nom. rev. to replace Enterobacteriaceae Rahn 1937, nom. fam. cons. (Opin. 15, Jud. Comm. 1958), which lost standing in nomenclature on 1 January 1980 . Int. J. Syst. Bacteriol. 30:674-675.

7. Farmer, J. J. III, D. J. Brenner, and W. H. Ewing. 1980 Opposition to recent proposals which would reject the family name Enterobacteriaceae and Escherichia as its type genus. Int. J. Syst. Bacteriol. 30:660-673.

8. Holmes, B., and R. J. Owen. 1979. Proposal that Flavobacterium breve be substituted as the type species of the genus in place of Flavobacterium aquatile and emended description of the genus Flavobacterium: status of the named species of Flavobacterium. Int. J. Syst. Bacteriol. 29:416-426.

9. Holt, J. G. 1979. International Committee on Systematic Bacteriology Judicial Commission. Minutes of the Meeting, 3 September 1978, Munich, West Germany. Int. J. Syst. Bacteriol. 29:267-269.

10. Judicial Commission. 1953. Minutes of the Judicial Commission meetings held at Rome in connection with the VI International Congress for Microbiology, September, 1953. Int. Bull. Bacteriol. Nomencl. Taxon. 3:141-154.

11. Judicial Commission. 1954. Opinion 13. Conservation and rejection of names of genera of bacteria proposed by Trevisan 1842-1890. Int. Bull. Bacteriol. Nomencl. and Taxon. 4:151-156.

12. Lapage, S. P. 1979. Proposal of Enterobacteraceae nom nov, as a substitute for the illegitimate but conserved name Enterobacteriaceae Rahn 1937. Request for an Opinion. Int. J. Syst. Bacteriol. 29:265-266.

13. Lapage, S. P., P. H. A. Sneath, E. F. Lessel, V. B. D. Skerman, H. P. R. Seeliger, and W. A. Clark (ed.). 1975. International code of nomenclature of bacteria. 1975 Revision. American Society for Microbiology, Washington, D.C.

14. Lessel, E. F. 1974. Judicial Commission of the International Committee on Systematic Bacteriology. Minutes of Meeting, 29 August 1973, Jerusalem, Israel. Int. J. Syst. Bacteriol. 24:379-380.

15. Skerman, V. B. D., V. McGowan, and P. H. A. Sneath (ed.). 1980. Approved lists of bacterial names. Int. J. Syst. Bacteriol. 30:225-420. 